\title{
Air quality modelling over Bogota, Colombia: Combined techniques to estimate and evaluate emission inventories
}

\author{
Erika Zárate $^{\mathrm{a}, *}$, Luis Carlos Belalcázar ${ }^{\mathrm{b}}$, Alain Clappier ${ }^{\mathrm{a}}$, Veronica Manzi ${ }^{\mathrm{b}}$, \\ Hubert Van den Bergh ${ }^{\mathrm{a}}$ \\ a Air and Soil Pollution Laboratory (LPAS), Swiss Federal Institute of Technology (EPFL), 1015-Lausanne, Switzerland \\ ${ }^{\mathrm{b}}$ Civil and Environmental Engineering Department, Universidad de los Andes, Carrera 1 No. 18A - 10, Bogota, Colombia
}

Received 13 October 2006; received in revised form 9 March 2007; accepted 13 March 2007

\begin{abstract}
Two versions of the Emission Inventory (EI) are generated for the city of Bogota, Colombia. In the first version (EI-1), CORINAIR traffic emission factors (EFs) are used. In the second (EI-2), bulk traffic EFs calculated for the city, using in situ measurements and inverse modelling techniques at street level, are used. EI-2 traffic emissions are 5, 4 and 3 times bigger than the corresponding values in EI-1, for $\mathrm{CO}, \mathrm{PM}_{10}$ and NMVOCs, respectively. The main goal of this study consists in evaluating the two versions of the EI when introduced into a mesoscale air quality model. The AOT (accumulated exposure over a threshold) index is calculated for comparison between observed and simulated concentrations of primary pollutants. Simulated concentrations using EI-2 are closer to the observed values. This comparison allows us to extract some conclusions of the methodology used to calculate the EFs. Local factors like the driving behavior, the altitude, vehicle technology and an aged fleet cannot be totally included and corrected in the standard methodologies, and seem to be more important than obtaining very detailed and precise information on the classification of the fleet or driving speeds. Under financially limited and fast changing situations, as in the case of many developing countries, a simple methodology to estimate bulk traffic EFs and to evaluate the EI, is of utmost importance. The use of combined techniques such as in situ measurements to estimate bulk traffic EFs, and further evaluation of the inventories with numerical models, proved to be a useful tool for this purpose.
\end{abstract}

(C) 2007 Elsevier Ltd. All rights reserved.

Keywords: Bogota; Emission inventory; Real-world emissions; Urban air pollution; Air quality management

\section{Introduction}

Urban agglomerations are major sources of regional and global atmospheric pollution. This case is especially severe in cities of developing

\footnotetext{
*Corresponding author. Tel.: +41216932726; fax: +41216933626 .

E-mail address: erika.zarate@epfl.ch (E. Zárate).
}

countries, where population, traffic, industrialization and energy use increase as people continue to migrate to the cities (Mage et al., 1996). Consequently, it is urgent to develop an air quality management policy and to establish strategies of atmospheric pollution prevention and control for such cities. Main limitations are, however, that either environmental authorities are not always effective, or air pollution mitigation may not be 
an immediate priority for the city (Mayer, 1999). Even if it is, there may be a strong lack of information and knowledge. Bogota, capital of Colombia, is to some extent a representative case of the latter condition. By 2001, it had reached 6.6 million inhabitants inside the urban perimeter (Skinner and Reinhard, 2004) and about 8.0 million taking into account the suburbs. It is the 5th biggest city in Latin America with nearly one million vehicles circulating every day, among which 50000 are diesel-powered heavy vehicles. Bogota $\left(4.6^{\circ} \mathrm{N}\right.$ and $74.1^{\circ} \mathrm{W}$ ) lies in a plateau placed in one of the three Andean mountain ranges crossing the country. The plateau is about $40 \mathrm{~km}$ wide and $100 \mathrm{~km}$ long, and aligned from the southwest to the northeast. It has an average elevation of 2600 masl, while mountainous complex terrain borders the plateau (Fig. 1(a)).

Bogota has an air quality monitoring network administrated by the DAMA (Departamento Técnico Administrativo del Medio Ambiente). Since 1997, it has been registered that the air quality standards of $\mathrm{PM}_{10}\left(170 \mu \mathrm{g} \mathrm{m}^{-3}, 24 \mathrm{~h}\right.$ average $), \mathrm{O}_{3}$ (83 ppb, hourly average) and $\mathrm{NO}_{2}$ (168 ppb, hourly average) are frequently exceeded. For example, in 2001 those standards were exceeded 281 times out of 49913 hourly measurements for $\mathrm{O}_{3}$ (seven monitoring stations) and 510 times out of 98612 hourly measurements for $\mathrm{PM}_{10}$ (14 monitoring stations).
The maximum values attained during the same year were $393 \mu \mathrm{g} \mathrm{m}^{-3}(1 \mathrm{~h})$ for $\mathrm{O}_{3}$ and $225 \mu \mathrm{g} \mathrm{m}^{-3}(24 \mathrm{~h}$ average) for $\mathrm{PM}_{10}$. The center and southwest parts of the city are highly polluted zones (Fig. 1(b)): MMA and Cazuca stations indicate the most frequent exceedances for $\mathrm{O}_{3}$, Merck and Sony stations for $\mathrm{PM}_{10}$, and Nacional and MMA for $\mathrm{NO}_{2}$ (DAMA, 2006).

Aiming to improve air quality in Bogota, the research project entitled Development of an air quality management system for Bogota was conceived. This project comprises the development of a set of tools which will facilitate the understanding and management of the air pollution problem in the city. Uncertainty regarding the response of pollutant concentrations to reductions of emissions, has made of modelling an essential tool to test abatement strategies (Vivanco and Andrade, 2006; Martilli et al., 2003); hence meteorological modelling in combination with air quality simulations is part of the set of tools to be developed. The modelling in turn will depend on an optimal spatially and temporally distributed emission inventory (EI). The goal of the project is to quantify emissions and to evaluate their implications on air quality, by applying a combined meteorologicalphotochemical air pollution model to the case of Bogota. The ultimate purpose is to implement efficient pollution control plans, following a careful

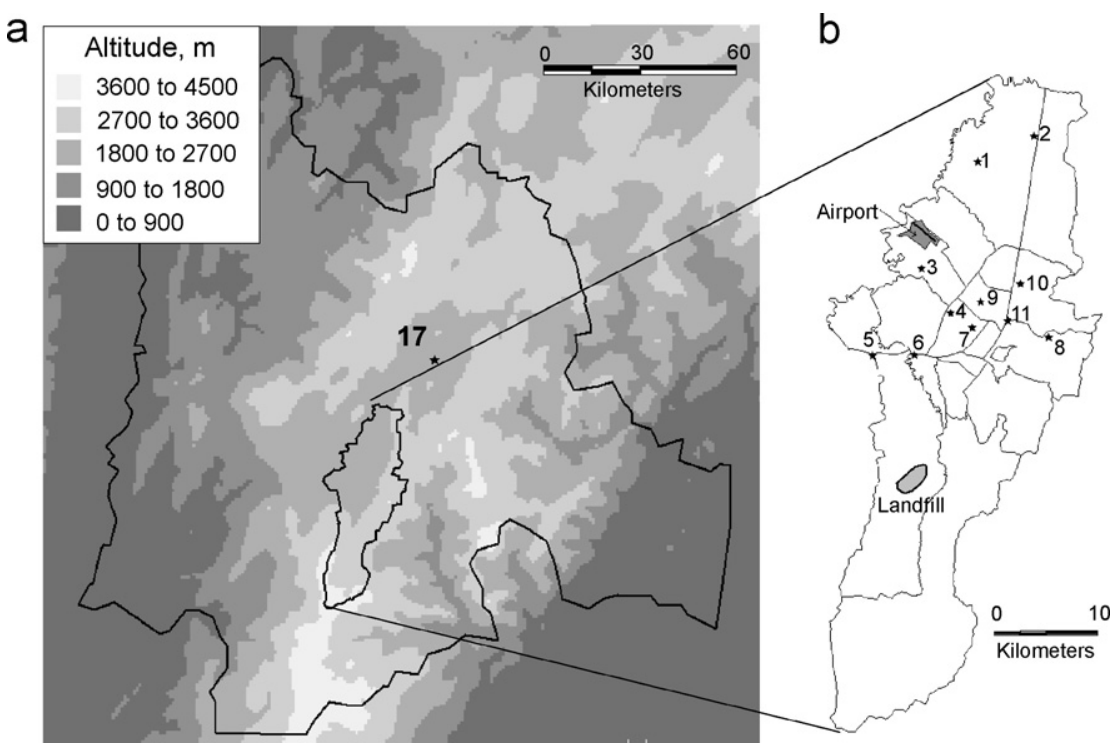

Fig. 1. Domain chosen for the emission inventory and simulations. (a) Topography of the domain of study $(212 \mathrm{~km} \times 212 \mathrm{~km}$, lower left corner $3.9^{\circ} \mathrm{N}$ and $75.0^{\circ} \mathrm{W}$ ) and city of Bogota. Cundinamarca department and Bogota's urban perimeter are delimited in thick black. Monitoring station number 17 (Duque) is also shown. (b) Bogota's urban perimeter, street network and measuring stations: 1. Corpas, 2. Escuela, 3. Fontibón, 4. Merck, 5. Cazucá, 6. Sony, 7. Cade, 8. Monserrate, 9. Nacional, 10. Santo Tomás, 11. MMA. 
cost benefit analysis. A series of articles is currently being prepared in order to present the main contributions of this case study. Up to now, a comprehensive spatially and temporally resolved EI did not exist for Bogota, neither have up to date photochemical models been applied to the region. The present paper is devoted to the presentation and evaluation of the EI for Bogota, 2002 being chosen as the base year. Problems encountered while completing the EI are presented, as well as the solutions adopted. This is of paramount importance because the lack of information and knowledge on emissions is a frequent situation when working on air pollution case studies in developing countries (e.g. Gurjar et al., 2004; Wang et al., 2005; Vivanco and Andrade, 2006). Consequently, finding adequate solutions to quantify emissions in a rapidly changing environment is often a major challenge for such countries.

Detailed EIs of air pollutants from human activities and natural sources are a first essential step towards understanding, controlling and mitigating air pollution; since the composition of the atmosphere is directly related to the emission fluxes (Taghavi et al., 2005). Two main methodologies can be applied when building an EI (Friedrich and Reis, 2004), namely bottom-up (based on in site information on emissions and activity data, it implies a big effort in data collection and it relies on emission models), and top-down (independent estimates of emissions based for example on analysis of statistical data, which are often not detailed enough for modelling purposes). Many authors (Friedrich and Reis, 2004; Vivanco and Andrade, 2006; Parrish, 2006 among others) recommend a combination of both methodologies; when their estimates agree, EIs are then considered to be more reliable.

Within the framework of this project a bottom-up approach is used to build our EI. The emission model AIREMIS (ACRI, 2000), which is based on CORINAIR methodologies (EEA, 1999), is used for this purpose. Two main types of data are needed: activity data (for example data on on-road vehicle sources like the average trip length, number of vehicles circulating per hour and per road, their average speed, etc.) and emission rate data, that is, emission factors (EFs). The first group of information represents a challenge in the case of Bogota because often the required data are not available.

For the second group of information, in the case of Europe for example, large databases of EFs exist, like those proposed by CORINAIR. Nevertheless, there is still an important uncertainty regarding precise real-world emissions. We focus our interest on on-road traffic because this source is among the main contributors to air pollution at urban sites (Rappenglück et al., 2000; Na et al., 2003; Vivanco and Andrade, 2006; Parrish, 2006). The project BAB II (Karlsruhe BundesAutoBahn campaign (Germany), Corsmeier et al., 2005), shows an example of the differences that can be found between model-calculated and real-world on-road traffic EFs. $\mathrm{CO}$ and $\mathrm{NO}_{x}$ emissions are underestimated by the emission model by about $23 \%$ and $17 \%$, respectively. For NMHC, the underestimation depends on the chemical species, but it can go up to a factor of about 20 times. The accuracy of mobile emission estimates have been questioned by many studies (Wang et al., 2005; Vivanco and Andrade, 2006; Parrish, 2006), suggesting the need of verification of the inventories and EFs. Traffic EFs depend to a large degree on the driving conditions and therefore can vary depending on the location (Berkowicz et al., 2006). This is particularly relevant for Bogota, where traffic jams are frequent, roads are often in a poor state of repair, and travel times are long (Skinner and Reinhard, 2004). There have been many attempts to estimate better real-world mobile emissions in developing countries using different approaches, for example, in India and China (Gurjar et al., 2004; Wang et al., 2005) laboratory measurements were done using local driving conditions and motor vehicles. Mexico has worked on direct measurement of exhaust emissions using remote sensing techniques (Schifter et al., 2003) and mobile laboratory in chase techniques (Zavala et al., 2006), while some other studies have been done to validate the EI through comparison with observations such as the study made in Sao Paulo by Vivanco and Andrade (2006). Some other methodologies like the application of street canyon (SC) models compared to measurements have been applied (e.g. Olcese et al., 2001; Berkowicz et al., 2006). The general conclusion of these studies is that model-calculated traffic emissions are underestimated and further research is needed to bring modelled and real-world traffic emissions in closer agreement.

In this paper, two estimations of the Bogota's EI are presented and compared. In a first step CORINAIR traffic EFs are used for the calculation of the EI (in the following this EI will be labelled EI-1). An evaluation of the traffic EFs for Bogota was conducted afterwards, via a top-down methodology 
which combines measurements inside a SC and the inverse use of a dispersion model. In this study, total on-road vehicle emissions are calculated by replacing CORINAIR EFs by those obtained in our evaluation process, so as to obtain a second version of the EI (in the following this EI will be labelled EI2). Both EIs are tested using a state-of-the-art air quality model (AQM) as tool of comparison. The AQM is applied to the particular case of a photochemical episode which took place in Bogota during 6 and 7 March 2002 (and for which a measuring campaign was conducted). The simulated concentrations obtained using both versions of the EI are compared with measurements.

Section 2 of this paper presents the relevant information on activity data for each source of emission and the description of how the EI is built. In the case of traffic, a brief description of the methodology used for the calculation of Bogota's traffic EFs is presented (Section 2.2.2). In the last part of Section 2, results of the two versions of the EI are included. The evaluation and comparison of the EIs using the AQM is presented in Section 3. Section 4 includes the analysis and discussion of results once the EIs have been evaluated.

\section{Emission inventory data}

The general methodology for the preparation of the EI includes three main steps, taking into account that it will be used as input data of the AQM: definition of the temporal and spatial resolution of the inventory, source classification and calculation of emissions, and incorporation of the time-dependent source data into the grid defined for modelling. A temporal resolution of $1 \mathrm{~h}$ is used, and calculations are done for a given working day in March. As for the spatial resolution, the EI is calculated for the Cundinamarca department (Fig. 1(a)), which is included inside the grid used for modelling ( $212 \mathrm{~km}$ by $212 \mathrm{~km}$ with $4 \mathrm{~km}$ square cells). Emission calculations are first individually done by source for Cundinamarca and afterwards adjusted to the $4 \times 4 \mathrm{~km}$ cells (Fig. 2).

Four main sources are considered for the calculations: production and services (P\&S), air traffic, biogenic (Section 2.1), and on-road traffic (Section 2.2). For the former, two sets of EFs are used: CORINAIR EFs (Section 2.2.1) and Bogota's own EFs (Section 2.2.2). Emission estimations are done for $\mathrm{NO}_{x}, \mathrm{CO}, \mathrm{NMVOCs}, \mathrm{CO}_{2}, \mathrm{SO}_{2}, \mathrm{CH}_{4}$, and $\mathrm{PM}_{10}$. AIREMIS is used for calculations and spatial aggregations. Section 2.3 presents results for both EIs.

\subsection{Input data other than traffic}

\subsubsection{Production and services $(P \& S)$}

These sources are divided in point sources (industries and commercial establishments) and area sources (fuel commercialization and Bogota's landfill). DAMA furnished emission data inside the urban perimeter for 4818 point sources (Table 3 and Fig. 3), product of a detailed industrial EI carried

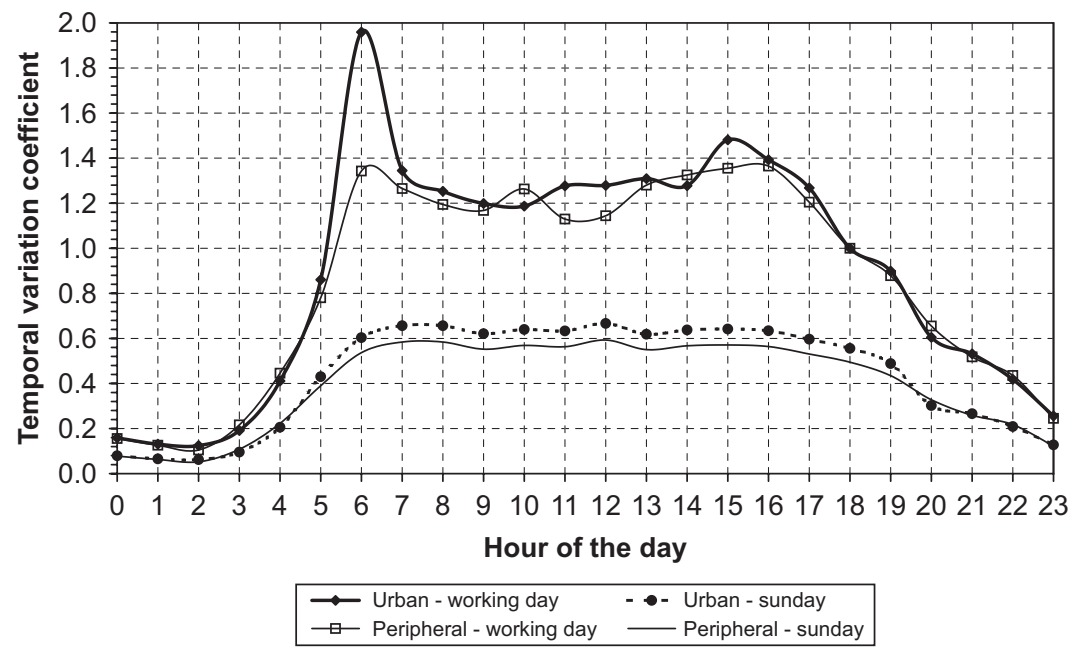

Fig. 2. Hourly coefficients of traffic distribution, per type of road. A value of 1.0 is attributed between 1800LT and 1900LT to both types of roads, peripheral and urban (highway not used in this study), for a working day. The rest of the coefficients are assigned based on the existing traffic counts in the city. 


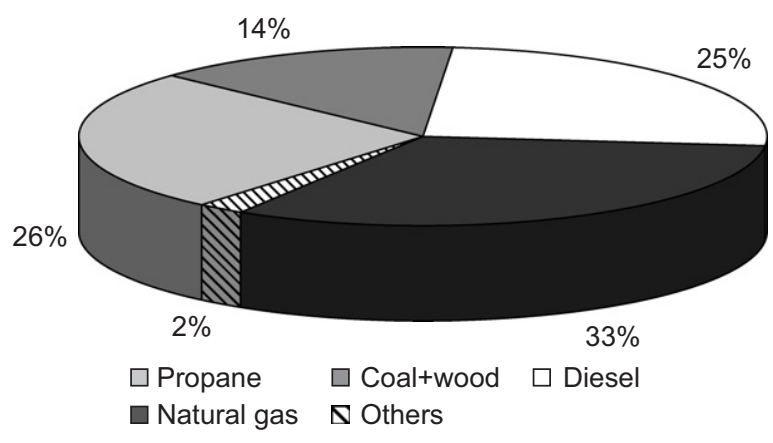

Fig. 3. Fuel usage for the 4818 records of point sources in Bogota. Other fuels are: crude oil, fuel oil, burned oil and gasoline. Source: DAMA/INAMCO (2001). Although 59\% of the industries are using propane and natural gas, a high percentage (16\%) uses coal, wood and other fuels of low quality.

out during 2001, using the AP-42 series EFs proposed by the EPA methodology (DAMA/ INAMCO, 2001; EPA, 2004). From the 4818 sources, 3194 are georeferenced. The remaining do not have an official address in agreement with DAMA's street network database. From the 3194 sources, 106 contribute with $95 \%$ of the total emissions (except NMVOC), so in this inventory they are considered as point sources inside the urban perimeter, and their emissions are input to AIREMIS (as furnished by DAMA). The remaining 4712 sources $4818-106)$ are grouped as area sources by district (Bogota's urban area is divided into 19 districts, Fig. 4). Most of the 106 point sources are situated in the Puente Aranda district, the most important industrial center in Bogota.

To cover the spatial resolution of the inventory described in this study, industries located outside the urban perimeter but inside Cundinamarca department are taken into account. A total number of 260 point sources, comprising two important industrial centers in the region (northern and western industrial corridors, Fig. 4), are used as input data. The existing information for these industries is very poor, an official detailed database does not exist (only by economical activity, Table 3 ), and information concerning fuel usage or temporal distribution is even more scarce. Either CORINAIR EFs or direct measurements of emissions, when available, are used for the calculations. For example, 91 of the 260 sources, correspond to brick factories. Existing emission measurements from a representative number of them are used as average input emission data for all of them, because EFs for some of the fuels used, such as crude oil, biomass,

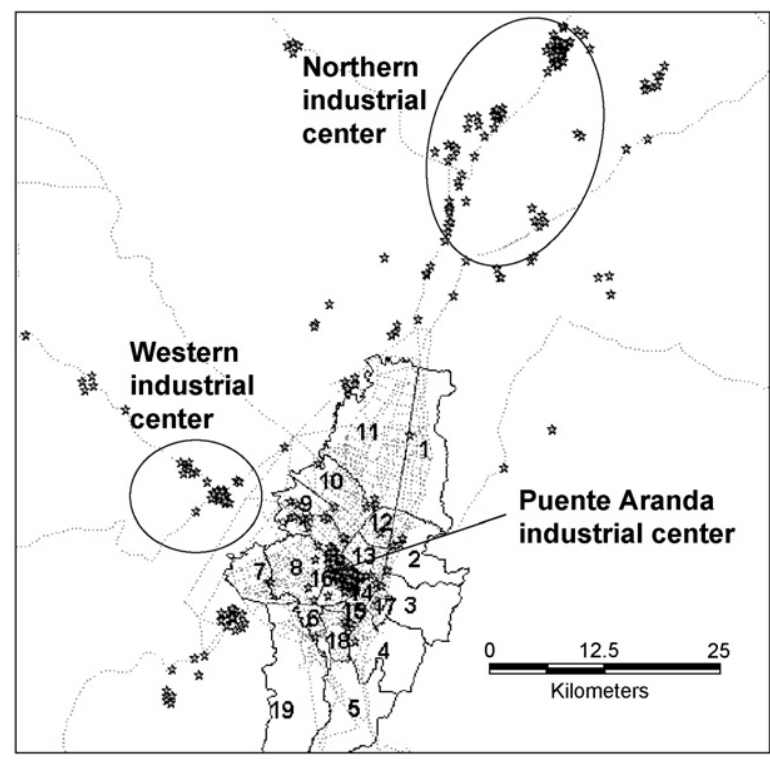

Fig. 4. Spatial distribution of the main point industrial sources around the region of Bogota. Three main industrial zones are shown: downtown Bogota (Puente Aranda district), and the northern and western industrial corridors. The administrative division of Bogota by localities is also depicted: 1. Usaquén, 2. Chapinero, 3. Santafé, 4. San Cristóbal, 5. Usme, 6. Tunjuelito, 7. Bosa, 8. Kennedy, 9. Fontibón, 10. Engativá, 11. Suba, 12. Barrios Unidos, 13. Teusaquillo, 14. Mártires, 15. Antonio Nariño, 16. Puente Aranda, 17. Candelaria, 18. Rafael Uribe, 19. Ciudad Bolívar.

tires, etc., do not exist. When possible, local characteristics of the fuels are used, as for example in the case of composition of the coal used.

EPA's methodologies and EFs (EPA, 2004) are used for the calculation of emissions coming from the commercialization of fuel (NMVOC emissions due to handling and selling gasoline) and the landfill $\left(\mathrm{CH}_{4}, \mathrm{CO}_{2}\right.$ and NMVOCs). Both are considered as area sources. For the first one, 19 area sources inside Bogota's urban perimeter (by district), and one area source for the rest of the Cundinamarca department. As for the landfill, one area source comprising the whole extension of it (Fig. 1(b)).

\subsubsection{Air traffic}

The airport in Bogota is located inside the city (Fig. 1). Emissions are calculated based on the georeferencing of the landing strip and the airport area, the air fleet composition, the total number of air operations per year and the temporal variations of them. EFs are those proposed by the MEET methodology (ACRI, 2000). Results appear as both linear (over the landing strip, while taking off and 
landing) and area (over the surface of the airport, while moving or parking) emissions, and are calculated at the ground level. Pollutants taken into account are: $\mathrm{CO}, \mathrm{NMVOC}, \mathrm{NO}_{x}$ and $\mathrm{SO}_{2}$. The total number of air operations during the year 2000 was 165497 (AEROCIVIL, 2002), value used as input for AIREMIS. Monthly, daily and hourly coefficients are applied to obtain the temporal distribution of the air operations (UNIAN DES, 2002).

\subsubsection{Biogenic sources}

The biogenic EI is important for modelling, because biogenic VOCs can contribute significantly to the formation of ozone (Stockwell et al., 1997; Rappenglück et al., 2000). Land use data (U.S. Geological Survey, 2002) grouped in three main types of biogenic sources (foliar forest, grasslands and other kinds of similar vegetation, and soils) is used for the calculation. The two first groups concern emissions of Isoprenoids, Terpenes and other VOCs, whereas the last one concerns Methane emissions. Although biogenic EFs are inherent to the existing vegetal species at a given place and time, those from CORINAIR (EEA, 1999) are used for this study, due to the lack of documentation in the geographical distribution of the vegetal species of the region and their EFs. Typical hourly values of temperature and Photosynthetically Active Radiation (PAR), for a day in the first dry season of the year, are used to compute these emissions.

\subsection{Input data for traffic}

\subsubsection{Classic methodology: CORINAIR EFs (EI-1)}

Traffic emissions are calculated using three main groups of activity data: the georeferenced street network, the fleet composition, and temporal and spatial variations of circulation and parking of this fleet. A traffic model is applied to the city (Reymond, 2002) to obtain the number of vehicles (and their average speed) circulating per segment of the street network between 1800LT and 1900LT of a given working day (this hour stands for the input information required by AIREMIS). The linear emission per segment is calculated based on CORINAIR velocity-dependent EFs according to the composition of the fleet and the type of road (highway, peripheral or urban). The emissions are computed hour per hour, using hourly coefficients which are given as input to the model for each type of road.
Total traffic emissions are calculated by summing emissions from two different sources, namely exhaust emissions and gasoline evaporation from cars. Exhaust emissions are at the same time divided into the thermally stabilized engine operation (hot engine) and the warming-up phase (cold start). Gasoline evaporation includes diurnal emissions, hot soak emissions and running losses. For both diurnal and hot soak emissions, GIS-based data of the economical distribution of the city, that is, the location of commercial, industrial and residential districts is used, in order to generate the corresponding area sources of emissions. Hourly temperatures expected for a given average day of the first dry season of the year (January, February and beginning of March) are also taken into account for this calculation.

Concerning the fleet circulating in Bogota, an official, complete and updated database does not exist. Bogota has a total of 989366 vehicles (684 428 registered in the city and 304938 registered outside the urban perimeter but with their owners having an address in Bogota, according to the state of the fleet in 2002, UNIAN DES (2002)). Six percent are equipped with diesel. This corresponds to buses, trucks and a few light duty vehicles and passenger cars $(1 \%)$, whereas the remaining $94 \%$ corresponds to gasoline passenger cars, light duty vehicles, minibuses, microbuses and vans. The database containing the information of the composition of the fleet by type and fuel has only 565613 entries. We apply the percentages of repartition from this database to the total number of vehicles (Tables 1 and 2). Splitting by classes (according to the engine capacity) is also required as input data for each type of vehicle. 382547 entries possess this information in the existing database, so input percentages to AIREMIS are based on information from these records (Table 3 ).

The hourly coefficients of traffic circulation (Fig. 2) per type of road are computed based on existing vehicle counts (UNIAN DES, 2002). The coefficient for the hour between 1800LT and 1900LT, the same hour for which the traffic model is run, has a value of 1 . The amount of vehicles circulating per hour is calculated by multiplying such coefficients by the traffic model results. Calculations for all the vehicles were done using an average trajectory length of $25 \mathrm{~km}$, which is the value reported by the Ministry of Transport (UNIAN DES, 2002). 
Table 1

Composition of Bogota's fleet ( $\%$ by year of production, state in 2002) for Gasoline passenger cars (GPC)

\begin{tabular}{lc}
\hline Production year & Percentage \\
\hline$<1972$ & 4.66 \\
$1972-1977$ & 7.90 \\
$1978-1980$ & 5.49 \\
$1981-1985$ & 9.91 \\
$1986-1992$ & 15.82 \\
$1993-1996$ & 20.97 \\
$1997-2000$ & 12.07 \\
$\geqslant 2001$ & 3.30 \\
Total & 80.12 \\
\hline
\end{tabular}

See Table 2 for the rest of the fleet distribution.

Table 2

Composition of Bogota's fleet ( $\%$ by year of production, state in 2002) for Gasoline light duty vehicles (GLDV), diesel passenger cars (DPC), diesel light duty vehicles (DLDV), heavy duty vehicles-trucks (HDV-T) and heavy duty vehicles-buses (HDV-B)

\begin{tabular}{lcclll}
\hline Production year & GLDV & DPC & DLDV & HDV-T & HDV-B \\
\hline$<1972$ & 1.47 & 0.02 & 0.00 & 0.98 & 0.40 \\
$1972-1991$ & 5.76 & 0.29 & 0.01 & 1.30 & 1.15 \\
$1992-1996$ & 4.05 & 0.25 & 0.01 & 0.34 & 0.52 \\
$1997-2000$ & 2.32 & 0.38 & 0.02 & 0.10 & 0.10 \\
$\geqslant 2001$ & 0.19 & 0.07 & 0.01 & 0.01 & 0.14 \\
Total & 13.80 & 1.01 & 0.04 & 2.72 & 2.31 \\
\hline
\end{tabular}

For GPC see Table $1 ; 55 \%$ of the total fleet is 10 years old or more at the moment of consulting the database. From the total fleet, $6 \%$ run with diesel, $94 \%$ with gasoline.

Table 3

Percentual distribution by economical activity in Bogota and Cundinamarca ${ }^{\mathrm{a}}$

\begin{tabular}{lll}
\hline Economical activity & Bogota & Cundinamarca \\
\hline Food and drink production & 14.8 & 28.9 \\
Textile industry & 2.5 & 3.2 \\
Shoe production & 4.3 & NA \\
Chemical industry & 4.1 & 16.5 \\
Plastic and rubber industry & 4.7 & 7.6 \\
Metallurgy and metal & 1.6 & 13.3 \\
products & & \\
Furniture manufacture & 6.8 & 12.9 \\
Non-metallic minerals & 0.1 & 15.8 \\
extraction and production & & \\
Manufacture of paper, & NA & 1.8 \\
cardboard and derivatives & & \\
Hotels, bars & 25.1 & NA \\
Miscellaneous & & NA
\end{tabular}

NA, not available.

a Sources: DAMA/INAMCO (2001); DANE (2004).

${ }^{\mathrm{b}}$ Miscellaneous comprises dry cleaning, printing, engineering services, etc.

\subsubsection{Estimation of Bogota's traffic EFs (EI-2)}

On-road traffic is the most important factor contributing to urban pollution in Latin American supercities. It is therefore of great importance to have reliable traffic EIs. We apply a simple and costeffective methodology to obtain real-world EFs for Bogota. A brief description of the methodology, which is based in the work made by Palmgren et al. (1999) and Olcese et al. (2001), is presented here (details can be found in Manzi et al., 2003). A new traffic EI is computed afterwards using the same methodology presented in Section 2.1.1, but replacing CORINAIR EFs by those obtained for Bogota.

The methodology used to obtain Bogota's EFs consists in the inverse application of a dispersion model within a SC with a high traffic circulation, assuming that it is representative of the general driving conditions and fleet circulating in the city. This methodology allows estimation of hot emissions within the $\mathrm{SC}$, and it is based on the premise that the street contribution to pollution $\left(C_{\mathrm{s}}\right.$, $\left.\left(\mathrm{g} \mathrm{m}^{-3}\right)\right)$ is the product of the local street traffic emissions submitted to a given dispersion, which is dependant on meteorological factors and the geometry of the SC:

$C_{\mathrm{s}}=D \cdot Q_{\mathrm{s}}$

where $D$ is the dispersion factor $\left[\mathrm{s} \mathrm{m}^{-2}\right]$ and $Q_{\mathrm{s}}$ is the emission rate of pollutant in the street $\left[\mathrm{g} \mathrm{m}^{-1} \mathrm{~s}^{-1}\right]$, which varies with the daily traffic. In order to evaluate $D$, the model STREET is used (Johnson et al., 1973; Berkowicz et al., 1997). It is empirically derived based on pollution measurements in a number of SCs and describes two formulations for $C_{\mathrm{s}}\left(C_{\mathrm{w}}\right.$ and $C_{\mathrm{l}}$, for the windward and leeward sides of the street). The formulation for $C_{1}$ can be found elsewhere (Berkowicz et al., 1997; Olcese et al., 2001); $C_{w}$ is expressed as

$C_{\mathrm{w}}=C_{\mathrm{s}}=\frac{k Q_{\mathrm{s}}}{w(u+0.5)} \frac{H-z}{H}=D \cdot Q_{\mathrm{s}}$,

where $H$ is the depth of the $\mathrm{SC}(\mathrm{m}), w$ is its width (m), $u$ the wind speed at roof level $\left(\mathrm{m} \mathrm{s}^{-1}\right), z$ the receptor height $(\mathrm{m})$, and $k$ a non-dimensional empirical constant. Releasing known amounts of passive tracer so that a line source inside the SC is simulated, and measuring its concentrations, $k$ is obtained. Eq. (2) can afterwards be inverted to calculate $Q_{\mathrm{s}}$ for the pollutants of interest, if their concentrations are also measured. 
$Q_{\text {s }}$ can be expressed as the total number of vehicles circulating per hour $\left(t_{\mathrm{F}}\right)$ times an average emission rate per mobile source $q,\left[\mathrm{~g} \mathrm{~m}^{-1} \mathrm{veh}^{-1}\right]$. Moreover, for two different types of vehicles (heavy and light):

$Q_{\mathrm{s}}=t_{\mathrm{F}} \cdot q=t_{\mathrm{FL}} \cdot q_{\mathrm{L}}+t_{\mathrm{FH}} \cdot q_{\mathrm{H}}$,

where $t_{\mathrm{FL}}$ and $t_{\mathrm{FH}}$ represent the hourly traffic counts for light and heavy vehicles (as mentioned before, light and heavy vehicles use mainly gasoline and diesel as fuel, respectively). $q_{\mathrm{L}}$ and $q_{\mathrm{H}}$ correspond to the average emission per mobile source $\left[\mathrm{g} \mathrm{m}^{-1} \mathrm{veh}^{-1}\right]$ for each vehicle category. Whenever hourly car counts are available, Eq. (3) is formulated. All the possible pairs of linearly independent equations are solved, in order to calculate separately $q_{\mathrm{L}}$ and $q_{\mathrm{H}}$, which correspond to the desired EFs in our study. The average values obtained are presented in Table 4.

These EFs are replaced in AIREMIS as velocityindependent, equal average values for every type of vehicle, separating only into two main types (light and heavy vehicles). A discussion on these results is presented in Section 4.2.

\subsection{Results of the EIs}

Table 5 presents the results of the EI by source for Bogota, and its percentages of contribution to total emissions in Cundinamarca. Two columns are presented for traffic, using CORINAIR (EI-1) and Bogota's (EI-2) EFs. This table shows how total traffic emissions increase 5, 4 and 3 times for $\mathrm{CO}$, $\mathrm{PM}_{10}$ and NMVOCs, respectively, after applying Bogota's EFs. A further discussion of these results will be presented in Section 4.

Table 4

Traffic emission factors found for Bogota, for light and heavy vehicles $^{\mathrm{a}}\left(\mathrm{g} \mathrm{km}^{-1} \mathrm{veh}^{-1}\right)$

\begin{tabular}{llll}
\hline Pollutant & Light & Heavy & Weighted average \\
\hline $\mathrm{CO}$ & $8.27 \pm 1.96$ & $385.2 \pm 142.3$ & $15.47 \pm 2.84$ \\
$\mathrm{NO}_{x}$ & $0.11 \pm 0.02$ & $18.9 \pm 0.37$ & $0.41 \pm 0.09$ \\
$\mathrm{PM}_{10}$ & 0.27 & 2.38 & $0.35 \pm 0.08$ \\
NMVOC & 5.58 & &
\end{tabular}

\footnotetext{
${ }^{\text {a }}$ Source: Manzi et al. (2003). Light vehicles include passenger cars and light duty vehicles; heavy duty vehicles include trucks and buses. The average EF obtained \pm the standard deviation is presented in this table.
}

Table 5

Total emissions by source for the urban perimeter of Bogota $\left(\text { ton } \text { day }^{-1}\right)^{\mathrm{a}}$

\begin{tabular}{|c|c|c|c|c|c|}
\hline \multirow[t]{2}{*}{ Pollutant } & \multicolumn{2}{|c|}{ On-road traffic } & \multirow[t]{2}{*}{$P \& S$} & \multirow[t]{2}{*}{ Air traffic } & \multirow[t]{2}{*}{ Biogenic } \\
\hline & EI-1 & EI-2 & & & \\
\hline $\mathrm{CO}$ & $165.0(73)$ & 838.8 (64) & $21.9(41)$ & $6.7(100)$ & - \\
\hline $\mathrm{NO}_{x}$ & $39.0(64)$ & $37.4(64)$ & $3.8(17)$ & $7.6(100)$ & - \\
\hline $\mathrm{PM}_{10}$ & $1.0(70)$ & $4.5(65)$ & $8.1(78)$ & - & - \\
\hline NMVOC & $42.6(83)$ & $130.4(68)$ & $12.1(78)$ & $3.2(100)$ & $0.03(0.4)$ \\
\hline $\mathrm{SO}_{2}$ & \multicolumn{2}{|l|}{$6.3(69)$} & $14.0(1)$ & $0.4(100)$ & - \\
\hline $\mathrm{CH}_{4}$ & \multicolumn{2}{|l|}{$1.4(77)$} & $132.7(100)$ & - & - \\
\hline $\mathrm{CO}_{2}$ & \multicolumn{2}{|l|}{$5133.4(70)$} & $1095.9(22)$ & - & - \\
\hline
\end{tabular}

${ }^{a}$ Numbers in parenthesis are the percentage of contribution of Bogota's emissions to total emissions over the studied domain. $\mathrm{P} \& S$, Production and Services.

\section{Evaluation of the EIs over a specific case study}

In order to assess the two versions of the EI, an $\mathrm{AQM}$ at the mesoscale level is applied. The goal is to compare the concentrations of $\mathrm{CO}, \mathrm{NO}_{x}$, NMVOCs and Ozone generated by the AQM for both EIs (EI-1 and EI-2). The AQM is applied to the 2-day photochemical episode during the dry season in 2002 (March 6 and 7). This test case represents a typical photochemical pollution situation often found during the dry seasons in the plateau of Bogota (see Section 3.2), and it is chosen because we rely on data from a measuring campaign which took place in the region for this period, allowing a better validation of the model. Simulated and observed concentrations are compared to evaluate the proximity of both EIs to measurements. Sections 3.1 and 3.2 present a brief description of the AQM and the meteorological situation in the region, respectively. Results of running the AQM for the two emission scenarios (EI-1 and EI-2) are presented in Section 3.3.

\subsection{Model description}

The models TAPOM (Transport and Air POllution Model, Martilli et al., 2003) and FVM (Finite Volume Model, Clappier et al., 1996), developed at LPAS (EPFL), are used for this study. They are three dimensional Eulerian models using terrain following grid and finite volume discretization. The transport and photochemistry model TAPOM includes the RACM lumped species mechanism (Stockwell et al., 1997), the Gong and Cho (1993) 
chemical solver for the gaseous phase, the ISORROPIA module for inorganic aerosols (Nenes et al., 1998), the passive transport of organic aerosols, and the solar radiation module TUV developed by Madronich (1998) to calculate the photolysis rate constants. Meteorological input data for TAPOM is obtained from the model FVM, whose borders can be forced using wind and temperature fields from large scale model results. FVM includes an urban turbulence module (Martilli et al., 2002, 2003) which specifically simulates the effects of urban areas on the meteorology. For both meteorological and air quality simulations, we use a domain of $212 \mathrm{~km}$ by $212 \mathrm{~km}$ (Fig. 1), with $4 \mathrm{~km}$ square cells and the city of Bogota in the middle. A pre-run of one day with the same emissions and wind fields is conducted for all the simulations, in order to provide more realistic initial conditions.

\subsection{Meteorological situation in the zone of study during the episode}

The episode chosen corresponds to a period of the year in which the general climatic conditions in the colombian Andes are dry and hot. During late December, January, February and early March, the intertropical convergence zone (ITCZ) is located at a latitude of about $2^{\circ} \mathrm{N}$, thus global scale winds (The Trade winds) come from the NE to the region of study. The influence of these winds is mainly seen over Bogota's plateau during the mornings, hence pollutants are pushed to the southwest of the city. As the sun heats up the ground throughout the day, a thermal wind predominates, air masses go up from the valleys and are pushed towards the East and Northeast, so pollutants are recirculated back over the city again. This meteorological behavior is representative of the first dry season of the year in the region, and it is of main interest since pollutants are brought back over the city towards the end of the morning, increasing exposition levels. The validation of meteorological and air quality simulations has been done using both data from Bogota's monitoring network and from the measuring campaign. It will be presented in separate articles which are currently being prepared.

\subsection{Comparison of simulated and observed surface concentrations}

A first comparison with primary pollutants is conducted. $\mathrm{CO}$ and $\mathrm{NO}_{x}$ are little influenced by the chemistry on the temporal scale of the order of a few hours (even if $\mathrm{NO}$ and $\mathrm{NO}_{2}$ are reactive, the total $\mathrm{NO}_{x}=\mathrm{NO}+\mathrm{NO}_{2}$ is little influenced by the chemistry). They are mainly influenced by dispersion and thus their concentrations are good indicators to evaluate the EI. Predicted daily CO concentrations using CORINAIR traffic EFs (EI-1) are much lower than the observed values and than those predicted with Bogota's traffic EFs (EI-2) (Fig. 5). Nightly peaks of $\mathrm{CO}$ are not well reproduced by the simulations, probably due to an inadequate distribution of the nightly wind field. For $\mathrm{NO}_{x}$ (Fig. 6), both simulations give similar results, since total $\mathrm{NO}_{x}$ traffic emissions do not differ much between both inventories (around 4\%, see Table 5), nevertheless, morning and nightly maximum concentrations are over-predicted at Nacional station. The hour of the morning peak, which is related to traffic, is generated by the model at $0900 \mathrm{LT}$, and it is in good agreement with observations.

In order to better evaluate results, the index $\mathrm{AOT}_{\text {min }}$ is calculated (Accumulated exposure Over a Threshold, is the surface under the curve of pollutant concentration time series above a certain threshold, in this case the threshold is the minimal concentration found for each curve), for both emission scenarios and observations, and for all the measuring stations. The difference in percentage between the $\mathrm{AOT}_{\text {min }}$ values obtained for the simulations and those obtained for the observations is computed for each station and afterwards averaged (Table 6). The simulation labelled EI-2 is closer to observations, especially for $\mathrm{CO}$, presenting an average percentual difference of $33 \%$, whereas simulation EI-1 presents $85 \%$. For $\mathrm{NO}_{x}$, percentual differences with respect to observations are smaller for EI-2, although not so different from EI-1 results. This indicates a clear underestimation of $\mathrm{CO}$ emissions in EI-1, whereas for $\mathrm{NO}_{x}$ both EI-1 and EI-2 generate similar results.

The model also shows how simulated concentrations of NMVOCs (Fig. 7) are much higher when using Bogota's EFs. Since there are no NMVOC measurements available, we proceed to examine Ozone concentrations (Fig. 8) as an indirect way to evaluate the impact of a change in the NMVOCs input emission data, although Ozone chemistry is strongly non-linear and concentrations depend on many other factors such as solar radiation and wind. On 6 March, the maximum measured $\mathrm{O}_{3}$ value is $149 \mathrm{ppb}$, attained at Nacional station, downtown Bogota. With both EIs, the model 

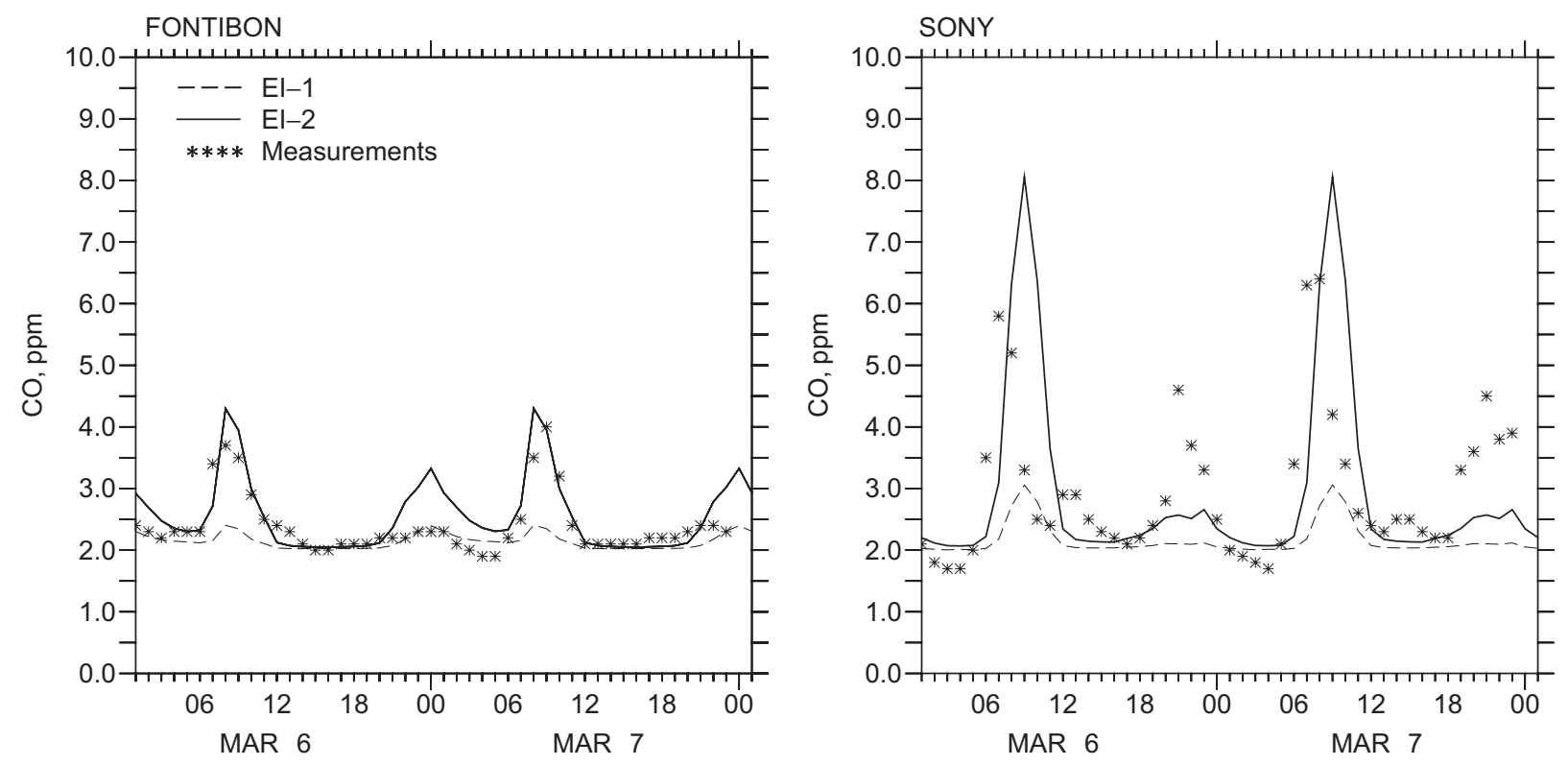

Fig. 5. Time series of observed (stars) and simulated CO concentrations in ppm using two versions of the emission inventory: EI-1 (dashed line) and EI-2 (solid line), 6 and 7 March 2002, for Fontibon and Sony measuring stations.
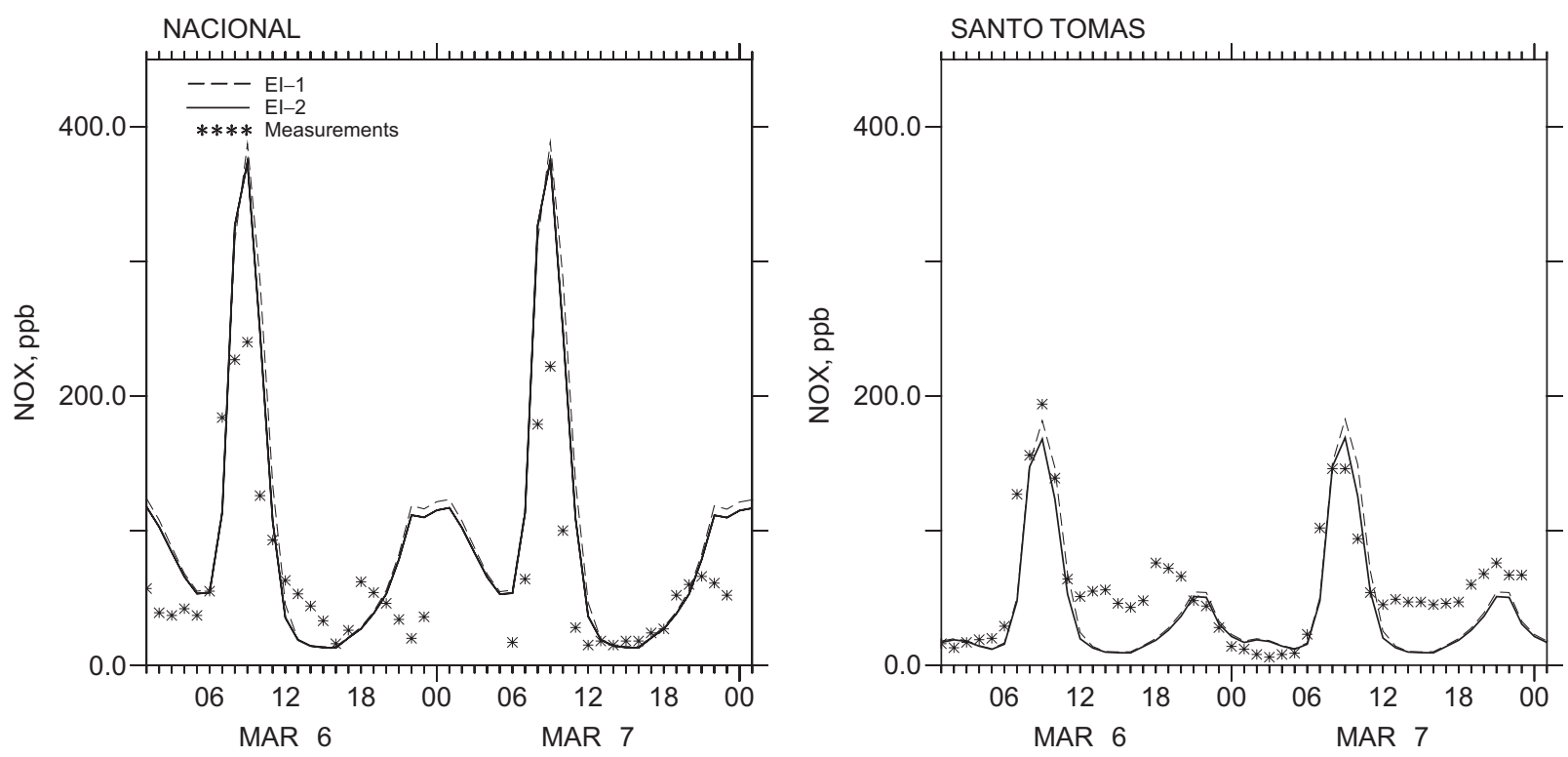

Fig. 6. Time series of observed (stars) and simulated $\mathrm{NO}_{x}$ concentrations in ppb using two versions of the emission inventory: EI-1 (dashed line) and EI-2 (solid line), 6 and 7 March 2002, for Nacional and Santo Tomas measuring stations.

reproduces an $\mathrm{O}_{3}$ maximum in the city center $(87$ and $107 \mathrm{ppb}$ for EI-1 and EI-2, respectively, at Nacional station), showing a better agreement for EI-2. On March 7, the maximum measured $\mathrm{O}_{3}$ value is attained at Monserrate station, towards the eastern part of the city (see Fig. 1), with $120 \mathrm{ppb}$ (not shown), whereas the model simulates a maximum in downtown, as the day before. This difference allows us to conclude that the meteorological conditions of the second day are not accurately reproduced by the model. Therefore, even if EI-1 simulated $\mathrm{O}_{3}$ values are closer to 
measurements in Nacional and Merck stations for the second day of simulation, we consider that the calculation using EI-2 simulates better the $\mathrm{O}_{3}$ production.

\section{Discussion and implications of the EI results}

Once both EIs have been evaluated and EI-2 is found to be more realistic, further conclusions are extracted based on it (Section 4.1). Afterwards, some limitations of the methodology are outlined (Section 4.2).

\subsection{Distribution of emissions by source and by region}

The most important contribution of $\mathrm{CO}$, NMVOC, $\mathrm{CO}_{2}$ and $\mathrm{NO}_{x}$ in Bogota is attributed

Table 6

Percentual difference between the $\mathrm{AOT}_{\text {min }}$ values computed for the two simulations (EI-1 and EI-2) and the observations

\begin{tabular}{llc}
\hline Pollutant & EI-1 & EI-2 \\
\hline $\mathrm{CO}$ & 85 & 33 \\
$\mathrm{NO}_{x}$ & 76 & 72
\end{tabular}

AOT values are calculated over the 2-day pollution episode ( 6 and 7 March 2002).

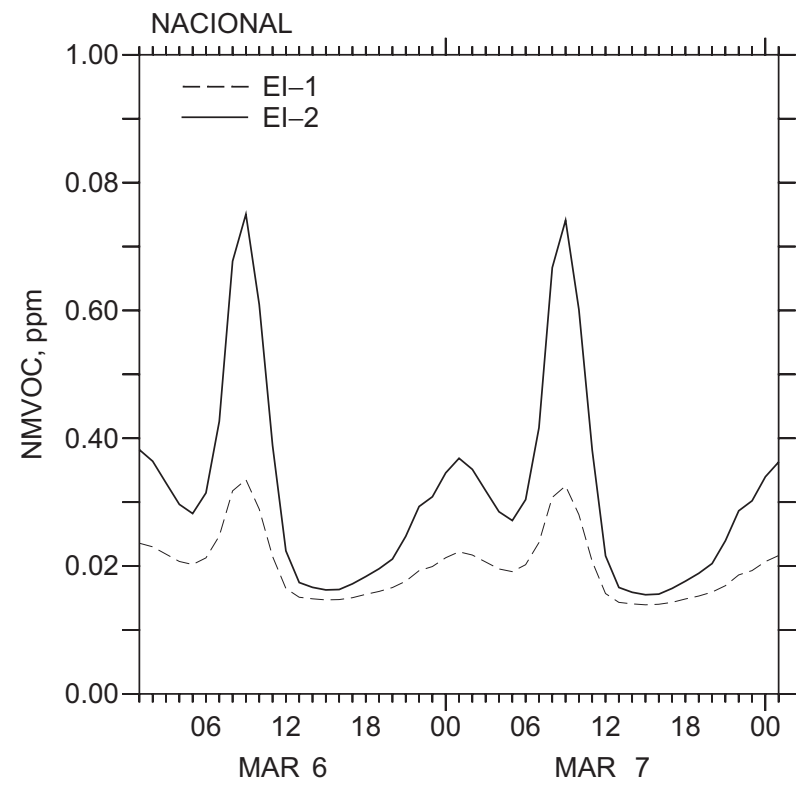

to traffic (Fig. 9). A similar relative source strength is found for other Latin-American cities such as Santiago and Mexico city (CONAMA, 2000; SMA, 2004), especially for $\mathrm{CO}$ and $\mathrm{NO}_{x}$. Fig. 10 shows the repartition of the on-road traffic emissions for light and heavy vehicles. For $\mathrm{PM}_{10}, \mathrm{NO}_{x}, \mathrm{CO}$ and $\mathrm{SO}_{2}$, the $99 \%, 96 \%, 84 \%$ and $65 \%$ of the total traffic emission, respectively, correspond to heavy vehicles (buses and trucks). This result is of main importance when considering that only $5 \%$ of the total fleet corresponds to heavy vehicles, using diesel as fuel. This small proportion of the fleet accounts for a large part of the air pollution in Bogota, and sheds light on where the environmental authorities should address their efforts. A similar situation is found in other cities like Sao Paulo (Colon et al., 2001; Vivanco and Andrade, 2006) and Mexico (Zavala et al., 2006), where only a small portion of the fleet is responsible of a large part of the total traffic emissions. Moreover, although the methodology described in this study is developed to determine emissions for only two vehicle classes (light and heavy), it would be very interesting to apply it (with more specific traffic counts) aiming to obtain emissions for different light vehicle categories, since, as in the case of Mexico City (Zavala et al., 2006), some particular gasoline powered light vehicle categories might account for a large percentage of the emissions.

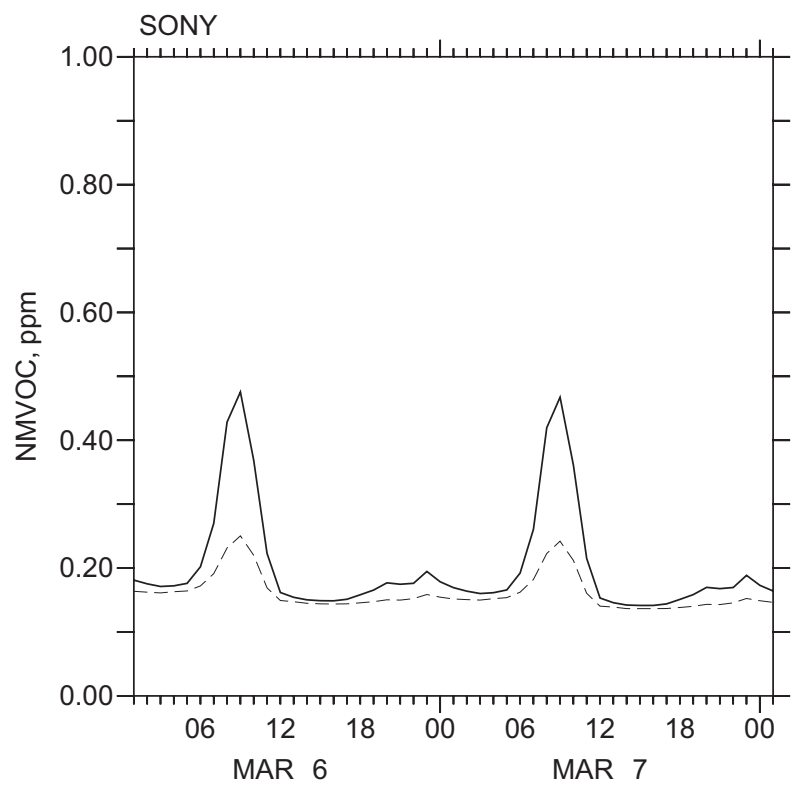

Fig. 7. Time series of simulated NMVOCs concentrations in ppm using two versions of the emission inventory: EI-1 (dashed line) and EI-2 (solid line), 6 and 7 March 2002, for Nacional and Sony stations. 

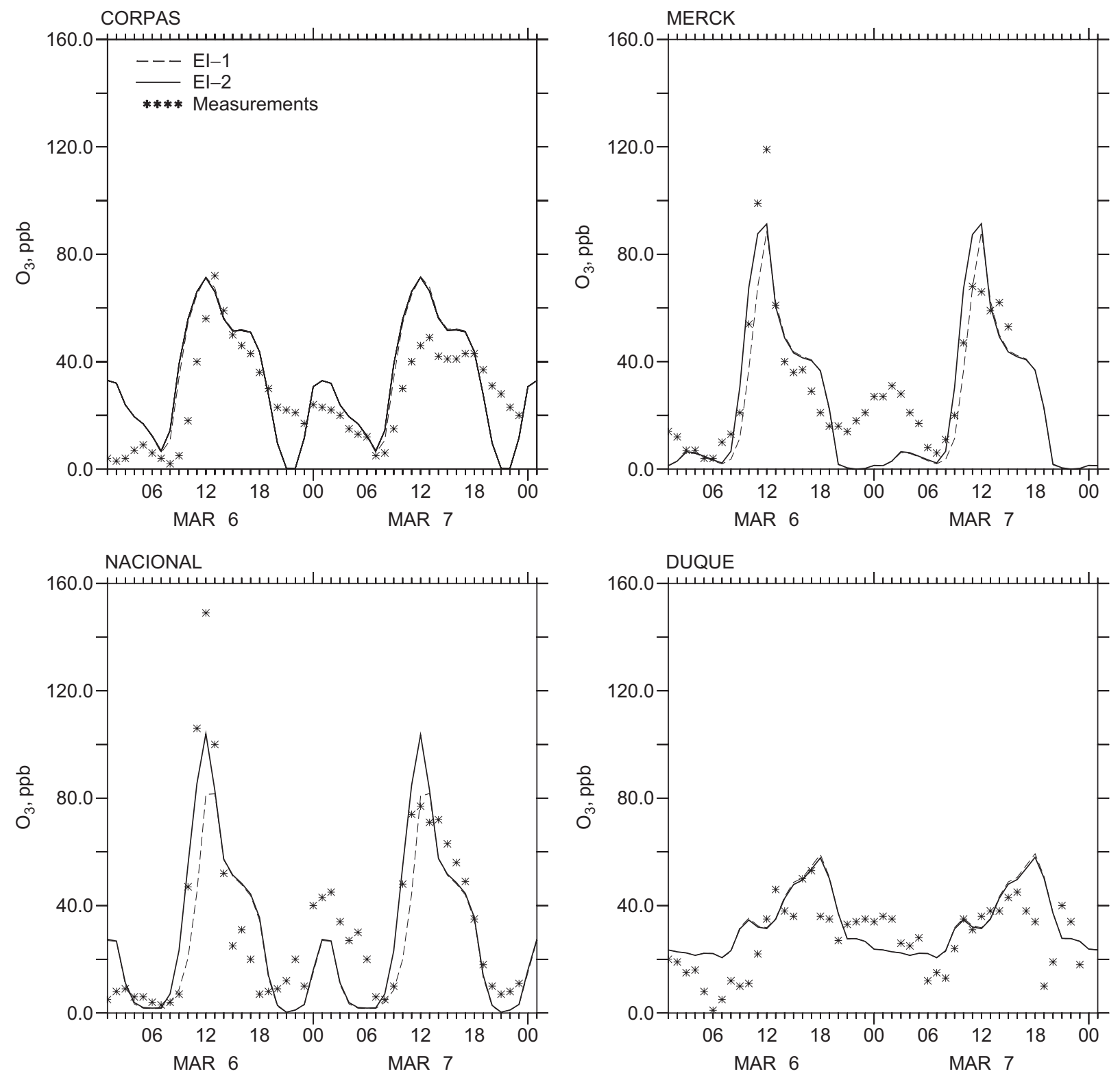

Fig. 8. Time series of observed (stars) and simulated $\mathrm{O}_{3}$ concentrations in ppb using two versions of the emission inventory: EI-1 (dashed line) and EI-2 (solid line), 6 and 7 March 2002, for Corpas, Merck, Nacional and Duque stations.

Total $\mathrm{NO}_{x}$ traffic emissions for EI-1 and EI-2 do not differ significantly. Nevertheless, a very important proportion of the emission $(96 \%)$ is attributed to heavy duty vehicles in EI-2. This high proportion may be partially attributed to the effects of altitude, as it has been shown by Bishop et al. (2001). However, $\mathrm{NO}_{x}$ is one of the species that is most influenced by the driving mode (Zavala et al., 2006), and the methodology described in this paper attempts to represent the average driving mode of a typical street in Bogota. It would be interesting to explore results of the application of the same methodology presented in this study, but for a street characterized by a different driving mode.

Fixed sources contribute mainly with $\mathrm{PM}_{10}$ and $\mathrm{SO}_{2}$. Concerning $\mathrm{PM}_{10}$, some sources were not taken into account in this EI, like construction, natural sources or resuspension and therefore this 


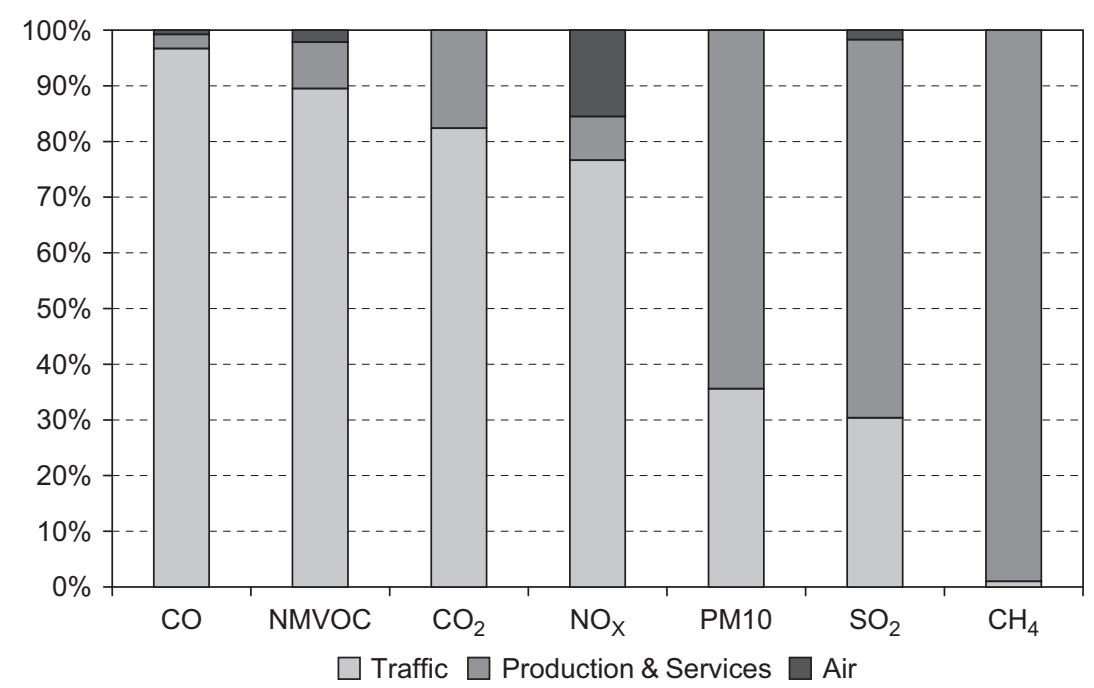

Fig. 9. Distribution of the emissions by source and pollutant in Bogota's urban perimeter. Biogenic emissions are mainly found outside the urban perimeter (not shown here).

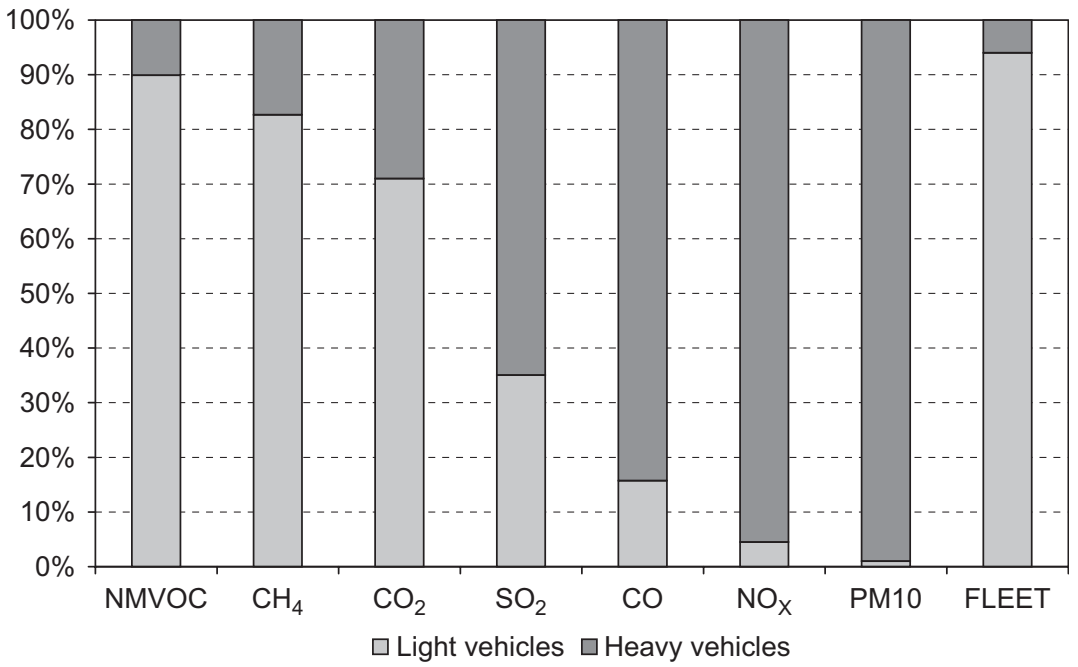

Fig. 10. Distribution of the on-road vehicle emissions in Bogota by type of vehicle and by pollutant.The last bar indicates the repartition of the fleet.

conclusion is not definitive. Further research is needed regarding $\mathrm{PM}_{10}$.

The spatial distribution of emissions (Fig. 11 and Table 7) indicates that downtown Bogota (cell ID's X21, Y20, Y21, Z20, Z21 and Z22) contributes with significant emissions of $\mathrm{CO}, \mathrm{PM}_{10}, \mathrm{NMVOC}$ and $\mathrm{NO}_{x}$. Those emissions are mainly related to traffic, and to a less extent to one of the main industrial centers in the city, located in Puente Aranda district (Fig. 4). The cell where the landfill is located (cell ID $\mathrm{X} 17$ ) contributes by far with the highest amount of
$\mathrm{CH}_{4}$ in the domain (this pollutant is not significant in the process of ozone production, but it is of interest for other reasons such as global warming and climate change). The cell where the airport is located (cell ID X23) indicates a significant contribution of $\mathrm{NO}_{x}$. Sixteen percent of the $\mathrm{NO}_{x}$ emissions in the city is coming from air sources. This result is important because it indicates that the proximity of the airport to the city may have important repercussions over air pollution, namely on the production of ozone. Another significant 


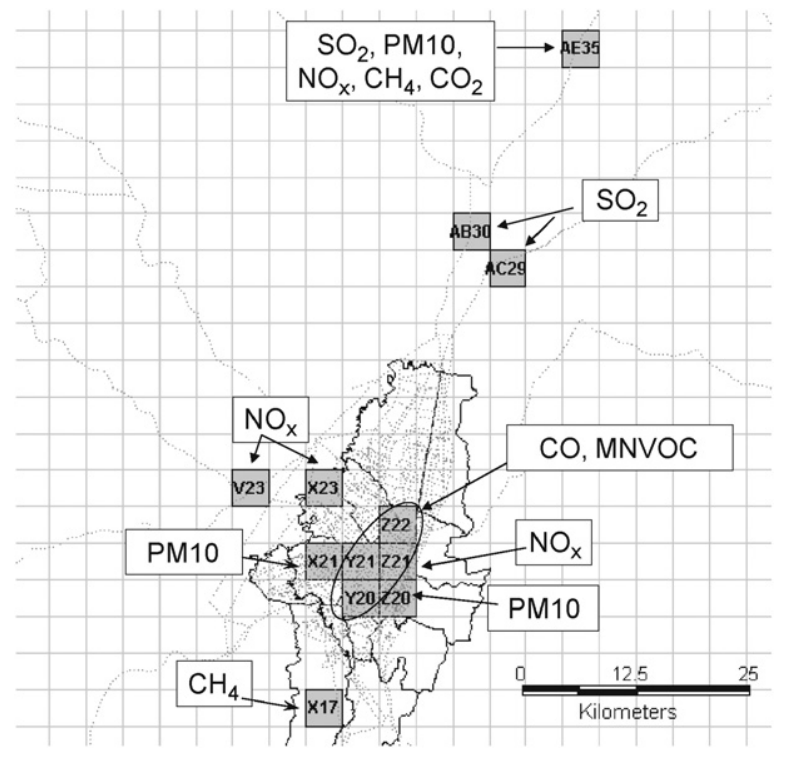

Fig. 11. Spatial distribution of the emissions in the region of Bogota. The most polluted cells in the domain of study are presented. The city center presents high levels of emissions for all the pollutants. Refer to Table 7 for data about emissions in these cells.

Table 7

Most polluted cells in the domain of study and their emissions

\begin{tabular}{lllll}
\hline Pollutant & \multicolumn{4}{l}{ Cell ID and emission (ton day ${ }^{-1}$ cell $^{-1}$ ) } \\
\hline $\mathrm{CO}$ & $Z 21$ & $Z 22$ & $Y 21$ & $Y 20$ \\
& 89.6 & 72.7 & 69.0 & 65.9 \\
$\mathrm{NO}_{x}$ & $X 23$ & $Z 21$ & $A E 35$ & $V 23$ \\
& 7.2 & 4.2 & 4.1 & 4.0 \\
$\mathrm{PM}_{10}$ & $Y 21$ & $X 21$ & $A E 35$ & $Z 20$ \\
& 2.7 & 1.9 & 1.6 & 1.1 \\
$\mathrm{NMVOC}^{*}$ & $Z 21$ & $Z 22$ & $Y 21$ & $Y 20$ \\
& 13.5 & 11.9 & 10.6 & 9.7 \\
$\mathrm{CH}_{4}$ & $X 17$ & $A B 30$ & $A E 35$ & $Z 21$ \\
& 132.2 & 0.3 & 0.2 & 0.1 \\
$\mathrm{CO}_{2}$ & $A B 30$ & $A E 35$ & $Y 21$ & $Z 21$ \\
& 1997.8 & 1476.7 & 663.8 & 534.0 \\
\hline
\end{tabular}

For each pollutant, the first line indicates the cell ID (the location of each cell is shown in Fig. 11) and the second its emission.

contribution of $\mathrm{NO}_{x}$ is seen in the western industrial corridor of the region. This $\mathrm{NO}_{x}$ is brought over the city contributing to the production of ozone (see Section 3.2). The northern industrial corridor (cell ID's AB30, AC29, AE35) points out important emissions of $\mathrm{PM}_{10}, \mathrm{NO}_{x}, \mathrm{CH}_{4}, \mathrm{SO}_{2}$ and $\mathrm{CO}_{2}$. This region is characterized among others by a number of brick manufactures operating with fuels like coal, crude oil, fuel oil, etc., and thus, generating important contributions to emissions.

\subsection{Limitations of the methodology and discussion}

The major shortcoming of the bottom-up methodology used to build our EI is the difficulty to obtain all the necessary input data. The incomplete data situation makes very difficult to conduct a full evaluation of uncertainties. We can state that uncertainties in our EI come from three main sources: first, the quality of the input data we have collected. Second, the extrapolation based on the existing information to fill in the remaining data gaps. Third, some aspects of the methodology itself and AIREMIS procedure, as it has been developed and applied by European countries and is not necessarily optimized for other countries.

In the second approach used for this study, bulk EFs are obtained for light and heavy vehicles regardless of a more complex composition of the fleet, and of variations in the driving speed (obtained EFs are assumed to be an average of the average driving speed measured inside the SC, $30 \mathrm{~km} \mathrm{~h}^{-1}$ ). Results from the previous section allow us to conclude that the inventory including Bogota's own on-road traffic EFs is more realistic (closer to measurements) than the one obtained using CORINAIR EFs. This means that at the present, for a city like Bogota, focusing efforts in obtaining EFs representative of the actual state of maintenance of the vehicle fleet, local driving patterns and effects due to the altitude, is more important than obtaining especially detailed and precise information of the fleet classification and its circulation speeds. The later should be conceived as to facilitate the identification of the biggest contributors. Although more research is needed in order to improve these EFs (for example, measurements could be conducted in more than one SC, for different driving speeds, more vehicle categories), the aggregated value of this methodology consists in its simplicity, relative low cost, the representation of real-word driving conditions at the altitude of Bogota, and the fact that it takes into account a large number of vehicles. On the other hand, a direct and quick evaluation of some abatement scenarios, which would need new on-road EFs, is not as simple as it is via a bottom-up methodology. Both methodologies are thus complementary.

An additional limitation of this methodology stands for the fact that the EI is evaluated on only one pollution event. We use this event because we rely on more data for validating its simulation and because it is particularly interesting since there is 
a recirculation of pollutants over the city due to a change in the wind direction, which is a common situation during the first dry season of the year. Nevertheless, conclusions remain only partial until simulating several pollution episodes or even applying long-term simulations.

Despite the limitations, a first version of Bogota's EI is accomplished, enhancing the knowledge about the spatial and temporal distribution of emissions in the region. The EI allows to identify the relative contribution of each source to pollution in the region, which will in turn help to recognize where efforts should be focused in order to improve the quality of the EI. Our results indicate that special attention should be given to heavy vehicles in Bogota, because they contribute crucially to air pollution in the city. Moreover, further investigations on emissions of this type of vehicles in Bogota are needed.

\section{Summary and outlook}

Two versions of the EI for Bogota have been established. First, calculations were done using CORINAIR on-road traffic EFs. Second, realworld EFs for Bogota were used for the calculation. These real-world EFs have been obtained by means of in-situ measurements and inverse modelling. A numerical model was used to evaluate the EIs, and emissions of $\mathrm{CO}, \mathrm{PM}_{10}$ and NMVOCs were found to be underestimated when using CORINAIR traffic EFs.

A comprehensive understanding of emissions is available for the first time in the region, pointing that on-road traffic sources represent a significant contribution of the EI. Though further investigation is required to fulfill the gaps in the missing information before emitting definitive conclusions, our results suggest that in particular heavy vehicles play a key role in the air pollution of the city, indicating where environmental authorities should focus their efforts.

The lack of complete databases and real-world EFs in many countries, represent a foremost limitation when building an EI. It is paradoxical that this lack of information is mainly found in countries contributing enormously to global emissions (Gurjar et al., 2004; Wang et al., 2005; Vivanco and Andrade, 2006 and many others), making uncertain the emission estimations. Improving the quality of data as to fulfill the requirements of the existing methodologies such as CORINAIR, is perhaps a very expensive and time-consuming task for such countries. In the case of Bogota, using a simple methodology to estimate bulk real-world on-road traffic EFs, we succeed in obtaining an EI which in turn generates pollutant concentrations (via the AQM) closer to observations for this specific case. Factors such as the stop-and-go driving behavior, the altitude, an aged fleet and the state of maintenance of the fleet, seem to be more important than obtaining very detailed information on the repartition of the fleet or driving speeds, for emission calculation purposes; at least as a first stage in the calculation. Consequently, under financially limited situations, a simpler methodology to estimate bulk traffic EFs might be of utmost importance. Moreover, the traffic situation is constantly changing in developing countries, and thus emissions. Efforts on improving methodologies able to quantify such changes periodically are crucial for those countries. The use of combined techniques such as measurements inside a SC to estimate traffic EFs, and further evaluation of the inventories with numerical models, proved to be a useful tool for this purpose. Nevertheless, the analysis presented here should be considered only as a first step towards a full evaluation of the EI. Further research is needed running the AQM for a longer period of time in order to draw final conclusions, as well as exploring the possibility to better couple both bottom-up and top-down techniques in order to optimize the evaluation of abatement scenarios.

\section{Acknowledgements}

We thank DAMA and the SDC (Swiss Agency for Development and Cooperation) for their financial support. We are also grateful to IDEAM (Instituto de Hidrología, Meteorología y Estudios Ambientales de Colombia) and CAR (Corporación Autónoma Regional de Cundinamarca) for providing meteorological data. We would like particularly to thank professor Diego Echeverry from UNIANDES, Dr. Eugenio Giraldo, Dr. Petra Seibert, Robinsson Rodriguez and Angela Castaño for their precious collaboration and support.

\section{References}

Aeronáutica Civil de Colombia (AEROCIVIL), 2002. 〈http:// www.aerocivil.gov.co/>. 
ACRI, 2000. Description du modèle AIREMIS. 〈http://www. acri.fr $/\rangle$.

Berkowicz, R., Hertel, O., Larsen, S.E., Sørensen, N.N., Nielsen, M., 1997. Modelling traffic pollution in streets. Ministry of Environment and Energy. Danish National Environmental Research Institute.

Berkowicz, R., Winther, M., Ketzel, M., 2006. Traffic pollution modelling and emission data. Environmental Modelling \& Software 21, 454-460.

Bishop, G.A., Morris, J.A., Stedman, D.H., Cohen, L.H., Countess, R.J., Countess, S.J., Maly, P., Scherer, S., 2001. The effects of altitude on Heavy-Duty Diesel Truck on-road emissions. Environmental Science \& Technology 35, 1574-1578.

Clappier, A., Perrochet, P., Martilli, A., Muller, F., Krueger, B.C., 1996. A new non-hydrostatic mesoscale model using a control volume finite element (CVFE) discretisation technique. In: Borrel, P.M., et al. (Ed), Proceedings of the EUROTRAC Symposium '96. Computational Mechanics Publications, Southampton, pp. 527-553.

Colon, M., Pleil, J.D., Hartlage, T.A., Guardani, M.L., Martins, M.H., 2001. Survey of volatile organic compounds associated with automotive emissions in the urban airshedof Sao Paulo, Brazil. Atmospheric Environment 35, 4017-4031.

Comisión Nacional del Medio Ambiente (CONAMA), 2000. Santiago de Chile. Inventario de Emisiones de la región metropolitana de Santiago 〈http://www.conama.cl/rm/568/ article-1104.html $\rangle$.

Corsmeier, U., Imhof, D., Kohler, M., Kühlwein, J., Kurtenbach, R., Petrea, M., Rosenbohm, E., Vogel, B., Vogt, U., 2005. Comparison of measured and model-calculated realworld traffic emissions. Atmospheric Environment 39, $5760-5775$.

Departamento Técnico Administrativo del Medio Ambiente (DAMA). Ingeniería ambiental del Colombia (INAMCO) 2001. Elaboración del inventario de fuentes fijas de emisión de contaminantes a la atmósfera en la ciudad de Bogota. Contrato 0792000.

Departamento Técnico Administrativo del Medio Ambiente (DAMA), Bogota, 2006 〈http://201.245.192.252/php/ 2006pm10.php $\rangle$.

Departamento Administrativo Nacional de Estadística (DANE), Bogota, Colombia. 2004 〈http://www.dane.gov.co//.

European Environment Agency (EEA). 1999. EMEP/CORINAIR. Emission inventory guidebook $\langle$ http://reports. eea.eu.int/EMEPCORINAIR4/en〉.

Friedrich, R., Reis, S., 2004. Emissions of Air Pollutants. Measurements, calculations and uncertainties. University of Stuttgart, Institute of Energy Economics and the Rational Use of Energy. ISBN 3-540-00840-3. Springer editions.

Gong, W., Cho, H., 1993. A numerical scheme for the integration of the gas phase chemical rate equations in three-dimensional atmospheric models. Atmospheric Environment 27A, 2147-2160.

Gurjar, B.R., van Aardenne, J.A., Lelieveld, J., Mohan, M., 2004. Emission estimates and trends (1990-2000) for megacity Delhi and implications. Atmospheric Environment 38, 5663-5681.

Johnson, W.B., Ludwig, F.L., Dabbert, W.F., Allen, R.J., 1973. An urban diffusion simulation model for carbon monoxide. Journal of the Air Pollution Control Association 23, 490-498.
Madronich, S., 1998. TUV tropospheric ultraviolet and visible radiation model /http://acd.ucar.edu/models/open/tuv/tuv. $\mathrm{html} /\rangle$.

Mage, D., Ozolins, G., Peterson, P., Webster, A., Orthofer, R., Vandeweerd, V., Gwynne, M., 1996. Urban air pollution in Megacities of the world. Atmospheric Environment 30, 681-686.

Manzi, V., Belalcázar, L., Giraldo, E., Zárate, E., Clappier, A., 2003. Estimación de los factores de emisión de las fuentes móviles de la ciudad de Bogota. Revista de Ingeniería de la Universidad de los Andes 18, 18-25 〈http://revistaing.uniandes. edu.co/index.php?s $=$ ar $\rangle$.

Martilli, A., Clappier, A., Rotach, M.W., 2002. An urban surface exchange parameterisation for mesoscale models. BoundaryLayer Meteorology 104, 261-304.

Martilli, A., Roulet, Y., Junier, M., Kirchner, F., Rotach, M., Clappier, A., 2003. On the impact of urban surface exchange parameterisations on air quality simulations: the Athens case. Atmospheric Environment 37, 4217-4231.

Mayer, H., 1999. Air pollution in cities. Atmospheric Environment 33, 4029-4037.

Na, K., Kim, Y.P., Moon, K.C., 2003. Diurnal characteristics of volatile organic compounds in the Seoul atmosphere. Atmospheric Environment 37, 733-742.

Nenes, A., Pandis, S., Pilinis, C., 1998. ISORROPIA: a new thermodynamic equilibrium model for multiphase multicomponent inorganic aerosols. Aquatic Geochemistry 4, $123-152$.

Olcese, L.E., Palancar, G.G., Toselli, B.M., 2001. An inexpensive method to estimate $\mathrm{CO}$ and $\mathrm{NO}_{x}$ emissions from mobile sources. Atmospheric Environment 35, 6213-6218.

Palmgren, F., Berkowicz, R., Ziv, A., Hertel, O., 1999. Actual car fleet emissions estimated from urban air quality measurements and street pollution models. The Science of the Total Environment 235, 101-109.

Parrish, D., 2006. Critical evaluation of US on-road vehicle emission inventories. Atmospheric Environment 40, 2288-2300.

Rappenglück, B., Oyola, P., Olaeta, I., Fabian, P., 2000. The evolution of Photochemical Smog in the Metropolitan Area of Santiago de Chile. Journal of Applied Meteorology 39, 275-290.

Reymond, Y., 2002. Transport et pollution de l'air à Bogotá. Raport de synthèse. Ecole Polytechnique Fédéral de Lausanne.

Skinner, Reinhard, 2004. City profile: Bogota. Cities 21, 73-81.

Schifter, I., Díaz, L., Durán, J., Guzmán, E., Chávez, O., LópezSalinas, E., 2003. Remote sensing study of emissions from motor vehicles in the Metropolitan Area of Mexico City. Environmental Science \& Technology 37, 395-401.

Secretaría del Medio Ambiente, Zona metropolitana del valle de México, 2004. Inventario de Emisiones a la atmósfera. 〈http:// www.sma.df.gob.mx/sma/modules.php?name = Aire $\rangle$.

Stockwell, W.R., Kircchner, F., Kuhn, M., 1997. New mechanism for regional atmospheric chemistry modelling. Journal of Geophysical Research 102, 25847-25879.

Taghavi, M., Cautenet, S., Arteta, J., 2005. Impact of a highly detailed emission inventory on modeling accuracy. Atmospheric Research 74, 65-88.

Universidad de los Andes, Ecole Polytechnique Fédéral de Lausanne, 2002. Primer Inventario de Emisiones. Third 
report of the project "Development and Implementation of an air quality model for Bogota". Departamento Técnico Administrativo del Medio Ambiente DAMA. Bogota.

U.S. Environmental Protection Agency (EPA). 2004 〈http:// www.epa.gov/ttn/chief/ap42/index.html $>$.

U.S. Geological Survey, $2002\langle$ http://edcsns17.cr.usgs.gov/glcc/〉.

Vivanco, M.G., Andrade, M., 2006. Validation of the emission inventory in the Sao Paulo Metropolitan Area of Brazil, based on ambient concentrations ratios of $\mathrm{CO}$, NMOG and $\mathrm{NO}_{x}$ and on a photochemical model. Atmospheric Environment 40, 1189-1198.
Wang, X., Mauzerall, D., Hu, Y., Russell, A.G., Larson, E., Woo, J., Streets, D., Guenther, A., 2005. A high-resolution emission inventory for eastern China in 2000 and three scenarios for 2020. Atmospheric Environment 39, 5917-5933.

Zavala, M., Herndon, S.C., Slott, R.S., Dunlea, E.J., Marr, L.C., Shorter, J.H., Zahniser, M., Knighton, W.B., Rogers, T.M., Kolb, C.E., Molina, L.T., Molina, M.J., 2006. Characterization of on-road vehicle emissions in Mexico City Metropolitan Area using a mobile laboratory in chase and fleet average measurement modes during the MCMA-2003 field campaign. Atmospheric Chemistry and Physics 6, 5129-5142. 